\title{
Assessment of the use of pheromone traps for catching click beetles in potato crops
}

\section{Ocena wykorzystania pułapek feromonowych do odłowów chrząszczy sprężykowatych w uprawach ziemniaka}

\author{
Magdalena Jakubowska ${ }^{*}$, Jan Bocianowski², Tomasz Erlichowski³ ${ }^{3}$ Jolanta Kowalska ${ }^{1}$
}

\section{Summary}

Damage to potato crops caused by feeding of click beetles larvae usually ranges from 5 to $25 \%$. On unprotected and ecological plantations, more than $50 \%$ of damaged tubers are noted. The aim of the study was to determine the species composition of Elateridae beetles caught and the dynamics of their occurrence on potato plantations. The beetles were caught using pheromone traps. The differences in the dynamics of occurrence of adult beetles between two research locations were also determined. The research was carried out in 2010-2012 in two potato plantations located in Poland, i.e. in the West Pomeranian Voivodeship and in the Subcarpathian Voivodeship. All caught beetles were marked in total to four Elateridae species belonging to the genus Agriotes spp. The results obtained after analysing the variance indicate a significant diversity in the individual years of research in the numbers of only Agriotes lineatus. The highest numbers of individuals of this species were observed in 2010 (average 62.5) and 2011 (average 82.08). Agriotes obscurus appeared less frequently in the study. On average, the highest number of individuals of this species were observed in the second year of the study (49.5)

Key words: click beetles, pheromone traps, monitoring, potato, Agriotes spp.

\section{Streszczenie}

Szkody w uprawach ziemniaka spowodowane żerowaniem larw sprężykowatych wynoszą zwykle od 5 do $25 \%$. Na plantacjach niechronionych i ekologicznych notowanych jest powyżej 50\% uszkodzonych bulw. Celem badań było określenie składu gatunkowego odłowionych chrząszczy Elateridae oraz dynamiki ich występowania na plantacjach ziemniaka. Chrząszcze odławiano za pomocą pułapek feromonowych. Określono również różnice w dynamice występowania osobników dorosłych między dwoma lokalizacjami badawczymi. Badania przeprowadzono w latach 2010-2012, w dwóch lokalizacjach uprawy ziemniaków w Polsce, tj. w województwie zachodniopomorskim i podkarpackim. Wszystkie odłowione chrząszcze oznaczono łącznie do czterech gatunków Elateridae należących do rodzaju Agriotes spp. Wyniki uzyskane po przeprowadzeniu analizy wariancji wskazują na istotne zróżnicowanie w poszczególnych latach badań w liczebności jedynie Agriotes lineatus. Największą liczebność osobników tego gatunku obserwowano w latach 2010 (średnio 62,5) i 2011 (średnio 82,08). Mniej licznie w doświadczeniu występował Agriotes obscurus. Średnio najwięcej osobników z tego gatunku obserwowano w drugim roku doświadczeń $(49,5)$.

Słowa kluczowe: sprężyki, pułapki feromonowe, monitoring, ziemniak, Agriotes spp.

\footnotetext{
${ }^{1}$ Instytut Ochrony Roślin - Państwowy Instytut Badawczy

Władysława Węgorka 20, 60-318 Poznań

${ }^{2}$ Uniwersytet Przyrodniczy w Poznaniu

Wojska Polskiego 28, 60-637 Poznań

${ }^{3}$ Agrico Polska Sp. z o.o., Staromiejska 7A, 84-300 Lębork

*corresponding author: m.jakubowska@iorpib.poznan.pl

ORCID: 0000-0001-9108-8965
} 


\section{Wstęp / Introduction}

W ostatnim czasie zaszły duże zmiany w strukturze produkcji roślinnej w Polsce. Istotnemu zmniejszeniu uległa liczba gospodarstw zajmujących się produkcją warzyw, ziemniaków, buraków cukrowych i zbóż, natomiast wzrosła liczba gospodarstw uprawiających rzepak i kukurydzę. Szczegółowa analiza najważniejszych upraw pozwala stwierdzić, że m.in. występowanie drutowców, czyli larw $\mathrm{z}$ rodziny Elateridae i innych szkodników glebowych, jest pośrednio związane z coraz powszechniej uprawianą kukurydzą na zielonkę i biogaz (uprawa głównie w monokulturach, które sprzyjają nagromadzaniu szkodników) (Bereś i wsp. 2007). W związku z zagospodarowaniem odłogów oraz użytków rolnych, na których stosuje się ograniczenia w uprawie płużnej, często mamy do czynienia z masowym występowaniem larw szkodników glebowych. Walka z nimi jest utrudniona ze względu na opóźnioną identyfikację oraz brak środków chemicznych możliwych do ich zwalczania. Susza i brak opadów w okresach wegetacji także wpływają w dużym stopniu na zwiększone uszkodzenie bulw, ponieważ larwy jako organizmy higrofilne szukają wody w bulwach ziemniaka, jeśli nie mają dostępu do poziomu wód gruntowych. Duże znaczenie ma także wzrost zachwaszczenia i zły wybór stanowiska pod ziemniaki. Żerowanie larw (drutowców) obserwuje się już po posadzeniu. Larwy sprężykowatych najczęściej w dużej liczbie spotyka się na glebach typu czarne ziemie lub zawierających dużą ilość próchnicy, o odczynie kwaśnym lub lekko kwaśnym (pH 5-6). Najmniej licznie stadia te zasiedlają gleby bielicowe o ubogim poziomie substancji próchniczych (Erlichowski 2010; Kapsa i wsp. 2014). Największe szkody drutowce wyrządzają na plantacjach zlokalizowanych na glebach ugorowanych lub odłogowanych, które ponownie poddano uprawie, a także na stanowiskach po wieloletnich monokulturach (kukurydza), po zlikwidowanych wieloletnich plantacjach bobowatych lub trawach - szczególnie w pierwszych latach ich użytkowania. W czasie wiosennej lub jesiennej uprawy roli, zwłaszcza w niesprzyjających warunkach (susza, nadmierna wilgotność, niska temperatura gleby) ocena występowania wielożernych szkodników glebowych może być utrudniona. Konieczne jest zatem wykonywanie analiz glebowych na obecność tych szkodników przed założeniem plantacji (Erlichowski 2008; Tratwal i wsp. 2018).

Zintegrowany system ochrony roślin przed drutowcami obejmuje m.in.: analizę stanu liczebności larw w glebie przed posadzeniem ziemniaków przy użyciu pułapek przynętowych lub odkrywek glebowych, wykorzystanie mechanizmów odporności roślin - tym samym, podatności odmian na uszkodzenia, stosowanie uprawek agrotechnicznych (podorywki, spulchnianie, orki) oraz kontrolowanie w okresie wegetacji liczebności chrząszczy sprężyków na plantacji za pomocą pułapek feromonowych. Ten sposób ochrony pól uprawnych przed larwami sprężyków może być jednym ze sposobów kontroli nasilenia szkodników glebowych na uprawianych plantacjach, w stosunku do przypadkowego ich zwalczania.

Odławianie samców sprężykowatych za pomocą pułapek feromonowych nie ma bezpośredniego wpływu na ograniczenie ich liczebności w środowisku. Osobniki dorosłe nie są bezpośrednimi sprawcami szkód - ich rola w środowisku rolniczym wiąże się z reprodukcją, składaniem jaj i rozpoczynaniem kolejnych cykli rozwojowych (Erlichowski 2009, 2011, 2014). Zadaniem pułapki feromonowej jest określenie liczebności sprężykowatych $\mathrm{w}$ danej lokalizacji oraz monitoring i przygotowanie strategii zwalczania na 1-2 lata przed właściwą uprawą ziemniaka (Jakubowska i Bocianowski 2014).

Celem badań było oznaczenie składu gatunkowego chrząszczy sprężykowatych odłowionych za pomocą pułapek feromonowych oraz określenie dynamiki ich występowania i zależności pomiędzy liczebnością osobników a lokalizacją uprawy ziemniaka.

\section{Materiały i metody / Materials and methods}

Badania dotyczące skuteczności odłowów chrząszczy sprężykowatych za pomocą pułapek feromonowych prowadzone były w województwie zachodniopomorskim w latach 2010-2012: w Boninie (53 $36^{\circ} 95^{\prime \prime} \mathrm{N}, 15^{\circ} 39^{\prime} 71^{\prime \prime} \mathrm{E}$; gmina

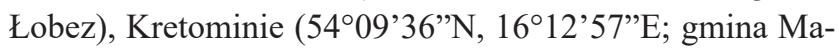
nowo) i Laskach Koszalińskich ( $54^{\circ} 08^{\prime} 25^{\prime}$ 'N, $16^{\circ} 04^{\prime} 57^{\prime \prime} \mathrm{E}$; gmina Biesiekierz) oraz $\mathrm{w}$ województwie podkarpackim

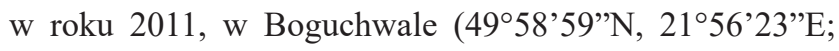
gmina Boguchwała). Odłowy dorosłych owadów prowadzono na plantacjach ziemniaków, które były w monokulturze. Obserwacje prowadzono na odmianach jadalnych ziemniaka, w trzech grupach wczesności (odmiany: Gracja, Gwiazda, Irga i Bryza), rekomendowane w latach 2010-2012. Pola z ziemniakami miały wielkość od 3 do 6 ha. W każdym roku badań, doświadczenia w wybranych lokalizacjach przeprowadzono według tej samej metodyki zakładającej stosowanie ogólnie przyjętych dla ziemniaka elementów i zabiegów agrotechnicznych.

Do odłowów dorosłych sprężyków z rodzaju Agriotes użyto pułapek feromonowych węgierskiej produkcji typu YATLORf $\mathrm{z}$ dyspenserami feromonowymi produkcji węgierskiej (firma Csalomon). Odławiano samce, takich gatunków jak: Agriotes lineatus (L.) (osiewnik rolowiec), Agriotes obscurus (L.) (osiewnik ciemny), Agriotes ustulatus (L.) oraz Agriotes sputator (L.) (osiewnik skibowiec) (Tóth i wsp. 2003; Jakubowska i Bocianowski 2014; Jakubowska i wsp. 2018).

Pułapki umieszczono na polach ziemniaka w terminach: od trzeciej dekady kwietnia do trzeciej dekady lipca w odległości 3-6 m od brzegu pola. Na każdej powierzchni badawczej umieszczono po dwie pułapki dla każdego gatunku 
Elateridae. Średnia wielkość poletka badawczego wynosiła od 1 do 3 ha. Systematycznie raz w tygodniu, sprawdzano zawartość pułapek, odnotowując liczbę złowionych samców poszczególnych gatunków. Co 4-5 tygodni wymieniano dyspenser.

Odłowione chrząszcze oznaczono korzystając z kluczy do oznaczania tych owadów (Boczek 1988; Piekarczyk 1993; Tarnawski 2000; Erlichowski 2007, 2008, 2009).

Przez cały okres prowadzenia doświadczenia monitorowano warunki pogodowe panujące na polu. Dane meteorologiczne uzyskano z polowych stacji meteorologicznych zainstalowanych na polach lub sąsiadujących $\mathrm{z}$ badaną plantacją.

Wyniki badań poddano analizie statystycznej, przy zastosowaniu jednoczynnikowej analizy wariancji (ANOVA), na poziomie istotności $\alpha=0,05$. Tą metodą weryfikowano hipotezę o braku wpływu lat prowadzenia badań na liczebność poszczególnych gatunków sprężykowatych. Podobnie, jednoczynnikowa ANOVA została przeprowadzona w celu zweryfikowania hipotezy zerowej o braku wpływu miejscowości na liczebności występowania chrząszczy poszczególnych gatunków. Współzależność pomiędzy liczebnością poszczególnych gatunków oceniono na podstawie współczynnika prostej korelacji liniowej Pearsona. Zmienność liczebności dwóch najliczniej odławianych gatunków sprężykowatych - A. lineatus i $A$. obscurus w poszczególnych latach prowadzenia obserwacji została przedstawiona na wykresach pudełkowych. Wszystkie obliczenia statystyczne wykonano za pomocą programu GenStat v. 10.1 (GenStat 2007).

\section{Wyniki i dyskusja / Results and discussion}

W okresie badawczym warunki meteorologiczne były bardzo zróżnicowane (tab. 4). Rok 2010 charakteryzował się suchą i chłodną wiosną. Panowały niekorzystne warunki agrotechniczne do rozwoju i wzrostu ziemniaków. Do czynników, które wpłynęły na niezbyt wysoki poziom plonów ziemniaka, należy zaliczyć między innymi nadmierne uwilgotnienie gleby na wielu plantacjach, co wiązało się z wcześniejszym i liczniejszym wystąpieniem chorób, zachwaszczeniem oraz trudnościami z przeprowadzeniem zabiegów agrotechnicznych (Walczak i wsp. 2011). Szczególnie korzystne warunki dla odłowów sprężyków stwierdzono w latach 2011-2012, bowiem odnotowano wówczas wysokie temperatury oraz umiarkowane opady, sprzyjające wychodzeniu dorosłych owadów z kryjówek oraz żerowaniu ich larw. W czasie upalnych dni okresowo występowało silne więdnięcie roślin okopowych. Notowana wysoka temperatura powietrza i gleby wpłynęła niekorzystnie na procesy zawiązywania i wzrostu bulw ziemniaka (Walczak i wsp. 2012, 2013).
Pierwsze osobniki osiewnika rolowca odłowiono na plantacjach ziemniaka na początku maja z wyjątkiem roku 2011 (Bonin) i 2012, w trzeciej dekadzie kwietnia (Kretomino). Szczyt liczebności tego gatunku obserwowano w maju i czerwcu. W poszczególnych latach badań najliczniej gatunek ten odławiano w Boninie w 2010 roku - 250 szt. i w 2011 roku - 404 szt. (tab. 1). W latach 2010-2012 gatunek $A$. obscurus (osiewnik ciemny) najliczniej odławiano w Boninie (2010 - 137 szt., 2011 - 343 szt., 2012 - 157 szt.) (tab. 1). Najmniej licznie odławiano gatunki $A$. sputator i A. ustulatus (2010 - 29 szt. i 2011 - 10 szt.).

Uzyskane wyniki wskazują także na istotny wpływ lat na liczebność $A$. lineatus (tab. 3). Największą liczbę osobników dorosłych osiewnika rolowca obserwowano w 2011 roku (rys. 1). Najmniej przedstawicieli omawianego gatunku zaobserwowano w ostatnim roku prowadzenia badań (rys. 1, tab. 1). Lata badań nie wpływały na dynamikę liczebności pozostałych sprężyków z rodzaju Agriotes (tab. 2). Nie zaobserwowano różnic pomiędzy liczbą odłowionych dorosłych sprężyków w poszczególnych miejscowościach (tab. 3). Wartości średnie oraz odchylenia standardowe dla czterech gatunków z rodzaju Agriotes w poszczególnych miejscowościach i latach obserwacji przedstawiono w tabeli 3. Na rysunku 2.

Tabela 1. Liczebność osobników Agriotes lineatus, Agriotes obscurus, Agriotes sputator i Agriotes ustulatus odłowionych do pułapek feromonowych w latach 2010-2012

Table 1. The number of specimens of Agriotes lineatus, Agriotes obscurus, Agriotes sputator and Agriotes ustulatus caught in pheromone traps in 2010-2012

\begin{tabular}{|c|c|c|c|}
\hline \multirow[t]{3}{*}{$\begin{array}{c}\text { Miejscowość } \\
\text { Location }\end{array}$} & \multicolumn{3}{|c|}{$\begin{array}{l}\text { Liczebność odłowionych sprężyków } \\
\text { w latach } \\
\text { The number of click beetles caught } \\
\text { in years }\end{array}$} \\
\hline & \multicolumn{3}{|c|}{ Agriotes lineatus } \\
\hline & 2010 & 2011 & 2012 \\
\hline Boguchwała & - & - & - \\
\hline Bonin & 250 & 404 & - \\
\hline Kretomino & - & - & 110 \\
\hline \multirow[t]{3}{*}{ Laski Koszalińskie } & - & - & - \\
\hline & \multicolumn{3}{|c|}{ Agriotes obscurus } \\
\hline & 2010 & 2011 & 2012 \\
\hline Boguchwała & - & - & - \\
\hline Bonin & 137 & 343 & 157 \\
\hline Kretomino & - & - & - \\
\hline \multirow[t]{3}{*}{ Laski Koszalińskie } & - & - & - \\
\hline & \multicolumn{3}{|c|}{ Agriotes sputator, Agriotes ustulatus } \\
\hline & 2010 & 2011 & 2012 \\
\hline Boguchwała & - & 10 & - \\
\hline Bonin & - & - & - \\
\hline Kretomino & - & - & - \\
\hline Laski Koszalińskie & 29 & - & - \\
\hline
\end{tabular}


Tabela 2. Jednoczynnikowa analiza wariancji dla liczebności chrząszczy sprężykowatych

Table 2. One-way analysis of variance for the population of click-beetles

\begin{tabular}{l|c|c|c|c|c|c|c|c}
\hline & \multicolumn{2}{|c|}{ Agriotes lineatus } & \multicolumn{2}{c|}{ Agriotes obscurus } & \multicolumn{2}{c|}{ Agriotes sputator } & \multicolumn{2}{c}{ Agriotes ustulatus } \\
\hline $\begin{array}{l}\text { Źródło zmienności } \\
\text { Source of variation }\end{array}$ & $\begin{array}{c}F \text { empir } \\
\text {-statistic }\end{array}$ & $\begin{array}{c}\text { wartość } p \\
p \text {-values }\end{array}$ & $\begin{array}{c}F \text { empir } \\
F \text {-statistic }\end{array}$ & $\begin{array}{c}\text { wartość } p \\
p \text {-values }\end{array}$ & $\begin{array}{c}F \text { empir } \\
F \text {-statistic }\end{array}$ & $\begin{array}{c}\text { wartość } p \\
p \text {-values }\end{array}$ & $\begin{array}{c}F \text { empir } \\
F \text {-statistic }\end{array}$ & $\begin{array}{c}\text { wartość } p \\
p \text {-values }\end{array}$ \\
\hline Lata - Years & 0,59 & 0,563 & 0,47 & 0,632 & 1,38 & 0,271 & 1,66 & 0,213 \\
\hline Miejscowości - Locations & 1,37 & 0,279 & 3,06 & 0,049 & 2,42 & 0,093 & 0,41 & 0,745 \\
\hline
\end{tabular}

Tabela 3. Wartości średnie i odchylenia standardowe liczebności chrząszczy rodzaju Agriotes spp.

Table 3. Mean values and standard deviations (s.d.) for number of species of the genus Agriotes spp.

\begin{tabular}{c|c|c|c|c|c|c|c|c}
\hline Rok-Year & \multicolumn{2}{|c|}{2010} & \multicolumn{2}{c|}{2011} & \multicolumn{2}{c|}{2012} & \multicolumn{2}{c}{$2010-2012$} \\
\hline $\begin{array}{c}\text { Miejscowość } \\
\text { Location }\end{array}$ & $\begin{array}{c}\text { średnia } \\
\text { mean }\end{array}$ & $\begin{array}{c}\text { odch. stand. } \\
\text { s.d. }\end{array}$ & $\begin{array}{c}\text { średnia } \\
\text { mean }\end{array}$ & $\begin{array}{c}\text { odch. stand. } \\
\text { s.d. }\end{array}$ & $\begin{array}{c}\text { średnia } \\
\text { mean }\end{array}$ & $\begin{array}{c}\text { odch. stand. } \\
\text { s.d. }\end{array}$ & $\begin{array}{c}\text { średnia } \\
\text { mean }\end{array}$ & $\begin{array}{c}\text { odch. stand. } \\
\text { s.d. }\end{array}$ \\
\hline
\end{tabular}

\begin{tabular}{l|c|c|c|c|c|c|c|c}
\multicolumn{9}{|c|}{ Agriotes lineatus } \\
\hline Boguchwała & $*$ & $*$ & $*$ & $*$ & $*$ & $*$ & $*$ & $*$ \\
\hline Bonin & 62,5 & 80,19 & 101 & 118,21 & $*$ & $*$ & 81,75 & 95,75 \\
\hline Kretomino & $*$ & $*$ & $*$ & $*$ & 27,5 & 20,47 & 27,5 & 20,47 \\
\hline Laski Koszalińskie & $*$ & $*$ & $*$ & $*$ & $*$ & $*$ & $*$ & $*$ \\
\hline Średnio - Mean & 62,5 & 80,19 & 101 & 118,21 & 27,5 & 20,47 & - & - \\
\hline
\end{tabular}

NIR $(0,05)$ - LSD (0.05) rok - year: 62,6; miejscowość - location: 52,3

\begin{tabular}{|c|c|c|c|c|c|c|c|c|}
\hline \multicolumn{9}{|c|}{ Agriotes obscurus } \\
\hline Boguchwała & $*$ & $*$ & $*$ & $*$ & $*$ & $*$ & $*$ & $*$ \\
\hline Bonin & 34,25 & 41,44 & 85,75 & 84,93 & 39,25 & 52,1 & 53,08 & 61,34 \\
\hline Kretomino & $*$ & * & $*$ & $*$ & $*$ & $*$ & $*$ & $*$ \\
\hline Laski Koszalińskie & $*$ & $*$ & $*$ & $*$ & $*$ & $*$ & $*$ & $*$ \\
\hline Średnio - Mean & 34,25 & 41,44 & 85,75 & 84,93 & 39,25 & 52,1 & - & - \\
\hline
\end{tabular}

NIR (0,05) - LSD (0.05) rok - year: 48,29; miejscowość - location: 36,73

\begin{tabular}{|c|c|c|c|c|c|c|c|c|}
\hline \multicolumn{9}{|c|}{ Agriotes sputator } \\
\hline Boguchwała & $*$ & $*$ & 2,00 & 2,45 & $*$ & $*$ & 2,00 & 2,45 \\
\hline Bonin & $*$ & $*$ & $*$ & $*$ & $*$ & $*$ & $*$ & $*$ \\
\hline Kretomino & $*$ & $*$ & $*$ & $*$ & $*$ & * & $*$ & $*$ \\
\hline Laski Koszalińskie & 6,75 & 9,74 & $*$ & $*$ & $*$ & $*$ & 6,5 & 9,95 \\
\hline Średnio - Mean & 6,75 & 9,74 & $*$ & $*$ & $*$ & $*$ & - & - \\
\hline
\end{tabular}

NIR (0,05) - LSD (0.05) rok - year: 4,09; miejscowość - location: 3,32

\begin{tabular}{|c|c|c|c|c|c|c|c|c|}
\hline \multicolumn{9}{|c|}{ Agriotes ustulatus } \\
\hline Boguchwała & $*$ & $*$ & 2,5 & 2,887 & $*$ & $*$ & 2,5 & 2,887 \\
\hline Bonin & $*$ & $*$ & 0,75 & 0,96 & $*$ & $*$ & 0,75 & 0,96 \\
\hline Kretomino & $*$ & $*$ & $*$ & $*$ & $*$ & $*$ & * & $*$ \\
\hline Laski Koszalińskie & 0,50 & 1,00 & $*$ & $*$ & $*$ & $*$ & 1,00 & 1,5 \\
\hline Średnio - Mean & 0,50 & 1,00 & 1,63 & 1,73 & $*$ & $*$ & - & - \\
\hline
\end{tabular}

NIR $(0,05)$ - LSD (0.05) rok - year: 0,655; miejscowość - location: 0,605

*brak danych - no data

przedstawiono dynamikę liczebności osiewnika ciemnego w poszczególnych latach prowadzenia obserwacji.

Współzależność pomiędzy dynamiką liczebności osobników czterech gatunków osiewników była oceniana na podstawie współczynników korelacji liniowej Pearsona.
Jedynie występowanie A. lineatus i A. obscurus było istotnie skorelowane $(\mathrm{r}=0,6197 ; \mathrm{p}=0,0012)$, prawdopodobnie dlatego, że zasiedlają podobne stanowiska (tab. 5).

Liczebność poszczególnych gatunków sprężykowatych odławianych do pułapek feromonowych była uzależniona 
Tabela 4. Przebieg pogody w Boninie (zachodniopomorskie) i Boguchwale (podkarpackie) w latach 2010-2012

Table 4. Weather conditions in 2010-2012 in Bonin (West Pomeranian Voivodeship) and Boguchwała (Subcarpathian Voivodeship)

\begin{tabular}{|c|c|c|c|c|c|c|}
\hline \multirow{2}{*}{$\begin{array}{l}\text { Rok } \\
\text { Year }\end{array}$} & \multirow{2}{*}{$\begin{array}{l}\text { Miesiąc } \\
\text { Month }\end{array}$} & \multirow{2}{*}{$\begin{array}{l}\text { Parametry pogodowe } \\
\text { Weather parameters }\end{array}$} & \multicolumn{3}{|c|}{ Dekada-Decade } & \multirow{2}{*}{$\begin{array}{c}\text { Średnia/suma miesięczna } \\
\text { Mean/sum monthly }\end{array}$} \\
\hline & & & I & II & III & \\
\hline \multicolumn{7}{|c|}{$\begin{array}{l}\text { Bonin (województwo zachodniopomorskie) } \\
\text { (West Pomeranian Voivodeship) }\end{array}$} \\
\hline \multirow{4}{*}{2010} & $\begin{array}{l}\text { kwiecień } \\
\text { April }\end{array}$ & $\begin{array}{l}\text { średnia temperatura dobowa powietrza } \\
\text { daily average air temperature }\left[{ }^{\circ} \mathrm{C}\right] \\
\text { opad - rainfall }[\mathrm{mm}]\end{array}$ & $\begin{array}{l}7,1 \\
0,3\end{array}$ & $\begin{array}{l}6,9 \\
9,0\end{array}$ & $\begin{array}{l}13,2 \\
11,2\end{array}$ & $\begin{array}{l}9,1 \\
20,5\end{array}$ \\
\hline & $\begin{array}{l}\text { maj } \\
\text { May }\end{array}$ & $\begin{array}{l}\text { średnia temperatura dobowa powietrza } \\
\text { daily average air temperature }\left[{ }^{\circ} \mathrm{C}\right] \\
\text { opad - rainfall }[\mathrm{mm}]\end{array}$ & $\begin{array}{l}9,9 \\
1,6\end{array}$ & $\begin{array}{l}8,6 \\
6,1 \\
\end{array}$ & $\begin{array}{l}11,1 \\
43,3\end{array}$ & $\begin{array}{l}9,9 \\
51,0\end{array}$ \\
\hline & $\begin{array}{l}\text { czerwiec } \\
\text { June }\end{array}$ & $\begin{array}{l}\text { średnia temperatura dobowa powietrza } \\
\text { daily average air temperature }\left[{ }^{\circ} \mathrm{C}\right] \\
\text { opad - rainfall }[\mathrm{mm}]\end{array}$ & $\begin{array}{l}17,8 \\
22,7\end{array}$ & $\begin{array}{l}18,0 \\
16,9\end{array}$ & $\begin{array}{c}18,9 \\
0\end{array}$ & $\begin{array}{l}18,2 \\
39,6\end{array}$ \\
\hline & $\begin{array}{l}\text { lipiec } \\
\text { July }\end{array}$ & $\begin{array}{l}\text { średnia temperatura dobowa powietrza } \\
\text { daily average air temperature }\left[{ }^{\circ} \mathrm{C}\right] \\
\text { opad - rainfall }[\mathrm{mm}]\end{array}$ & $\begin{array}{c}24,7 \\
0\end{array}$ & $\begin{array}{l}24,6 \\
2,4\end{array}$ & $\begin{array}{r}25,8 \\
1,1\end{array}$ & $\begin{array}{l}25,0 \\
3,5\end{array}$ \\
\hline \multirow{4}{*}{2011} & $\begin{array}{l}\text { kwiecień } \\
\text { April }\end{array}$ & $\begin{array}{l}\text { średnia temperatura dobowa powietrza } \\
\text { daily average air temperature }\left[{ }^{\circ} \mathrm{C}\right] \\
\text { opad - rainfall }[\mathrm{mm}]\end{array}$ & $\begin{array}{r}8,9 \\
12,4 \\
\end{array}$ & $\begin{array}{l}7,5 \\
6,6\end{array}$ & $\begin{array}{c}13,8 \\
0,6 \\
\end{array}$ & $\begin{array}{l}10,1 \\
19,6\end{array}$ \\
\hline & $\begin{array}{l}\text { maj } \\
\text { May }\end{array}$ & $\begin{array}{l}\text { średnia temperatura dobowa powietrza } \\
\text { daily average air temperature }\left[{ }^{\circ} \mathrm{C}\right] \\
\text { opad - rainfall }[\mathrm{mm}]\end{array}$ & $\begin{array}{l}9,3 \\
2,6\end{array}$ & $\begin{array}{l}14,0 \\
38,0 \\
\end{array}$ & $\begin{array}{l}15,5 \\
15,4\end{array}$ & $\begin{array}{l}12,9 \\
56,0\end{array}$ \\
\hline & $\begin{array}{l}\text { czerwiec } \\
\text { June }\end{array}$ & $\begin{array}{l}\text { średnia temperatura dobowa powietrza } \\
\text { daily average air temperature }\left[{ }^{\circ} \mathrm{C}\right] \\
\text { opad - rainfall }[\mathrm{mm}]\end{array}$ & $\begin{array}{l}17,9 \\
7,8\end{array}$ & $\begin{array}{l}15,3 \\
46,8\end{array}$ & $\begin{array}{l}16,4 \\
8,2\end{array}$ & $\begin{array}{l}16,5 \\
62,8\end{array}$ \\
\hline & $\begin{array}{l}\text { lipiec } \\
\text { July }\end{array}$ & $\begin{array}{l}\text { średnia temperatura dobowa powietrza } \\
\text { daily average air temperature }\left[{ }^{\circ} \mathrm{C}\right] \\
\text { opad - rainfall }[\mathrm{mm}]\end{array}$ & $\begin{array}{l}17,2 \\
30,4 \\
\end{array}$ & $\begin{array}{l}18,0 \\
40,0 \\
\end{array}$ & $\begin{array}{l}16,5 \\
50,6\end{array}$ & $\begin{array}{r}17,2 \\
121,0 \\
\end{array}$ \\
\hline \multirow{4}{*}{2012} & $\begin{array}{l}\text { kwiecień } \\
\text { April }\end{array}$ & $\begin{array}{l}\text { średnia temperatura dobowa powietrza } \\
\text { daily average air temperature }\left[{ }^{\circ} \mathrm{C}\right] \\
\text { opad - rainfall }[\mathrm{mm}]\end{array}$ & $\begin{array}{r}3,4 \\
19,2 \\
\end{array}$ & $\begin{array}{l}7,1 \\
7,6\end{array}$ & $\begin{array}{l}12,4 \\
11,0\end{array}$ & $\begin{array}{r}7,6 \\
37,8\end{array}$ \\
\hline & $\begin{array}{l}\text { maj } \\
\text { May }\end{array}$ & $\begin{array}{l}\text { średnia temperatura dobowa powietrza } \\
\text { daily average air temperature }\left[{ }^{\circ} \mathrm{C}\right] \\
\text { opad - rainfall }[\mathrm{mm}]\end{array}$ & $\begin{array}{l}12,4 \\
13,8 \\
\end{array}$ & $\begin{array}{l}12,2 \\
7,2 \\
\end{array}$ & $\begin{array}{c}15,0 \\
0\end{array}$ & $\begin{array}{l}13,2 \\
21,0\end{array}$ \\
\hline & $\begin{array}{l}\text { czerwiec } \\
\text { June }\end{array}$ & $\begin{array}{l}\text { średnia temperatura dobowa powietrza } \\
\text { daily average air temperature }\left[{ }^{\circ} \mathrm{C}\right] \\
\text { opad - rainfall }[\mathrm{mm}]\end{array}$ & $\begin{array}{l}12,8 \\
3,6\end{array}$ & $\begin{array}{l}16,0 \\
23,8\end{array}$ & $\begin{array}{l}15,7 \\
91,2\end{array}$ & $\begin{array}{l}14,8 \\
118,6\end{array}$ \\
\hline & $\begin{array}{l}\text { lipiec } \\
\text { July }\end{array}$ & $\begin{array}{l}\text { średnia temperatura dobowa powietrza } \\
\text { daily average air temperature }\left[{ }^{\circ} \mathrm{C}\right] \\
\text { opad - rainfall }[\mathrm{mm}]\end{array}$ & $\begin{array}{l}18,8 \\
39,6 \\
\end{array}$ & $\begin{array}{l}14,9 \\
92,6 \\
\end{array}$ & $\begin{array}{l}19,2 \\
15,2\end{array}$ & $\begin{array}{r}17,6 \\
113,8 \\
\end{array}$ \\
\hline
\end{tabular}

Boguchwała (województwo podkarpackie)

(Subcarpathian Voivodeship)

\begin{tabular}{|c|c|c|c|c|c|c|}
\hline \multirow{4}{*}{2011} & $\begin{array}{l}\text { kwiecień } \\
\text { April }\end{array}$ & $\begin{array}{l}\text { średnia temperatura dobowa powietrza } \\
\text { daily average air temperature }\left[{ }^{\circ} \mathrm{C}\right] \\
\text { opad - rainfall }[\mathrm{mm}]\end{array}$ & $\begin{array}{l}9,5 \\
16,0\end{array}$ & $\begin{array}{l}8,1 \\
12,7\end{array}$ & $\begin{array}{l}13,1 \\
21,3\end{array}$ & $\begin{array}{l}10,2 \\
50,0\end{array}$ \\
\hline & $\begin{array}{l}\text { maj } \\
\text { May }\end{array}$ & $\begin{array}{l}\text { średnia temperatura dobowa powietrza } \\
\text { daily average air temperature }\left[{ }^{\circ} \mathrm{C}\right] \\
\text { opad - rainfall }[\mathrm{mm}]\end{array}$ & $\begin{array}{l}9,2 \\
20,6\end{array}$ & $\begin{array}{l}15,0 \\
9,6\end{array}$ & $\begin{array}{l}17,5 \\
19,0\end{array}$ & $\begin{array}{l}13,9 \\
49,2\end{array}$ \\
\hline & $\begin{array}{l}\text { czerwiec } \\
\text { June }\end{array}$ & $\begin{array}{l}\text { średnia temperatura dobowa powietrza } \\
\text { daily average air temperature }\left[{ }^{\circ} \mathrm{C}\right] \\
\text { opad - rainfall }[\mathrm{mm}]\end{array}$ & $\begin{array}{l}19,6 \\
29,2\end{array}$ & $\begin{array}{l}17,4 \\
23,2\end{array}$ & $\begin{array}{l}17,2 \\
36,1\end{array}$ & $\begin{array}{l}18,1 \\
88,5\end{array}$ \\
\hline & $\begin{array}{l}\text { lipiec } \\
\text { July }\end{array}$ & $\begin{array}{l}\text { średnia temperatura dobowa powietrza } \\
\text { daily average air temperature }\left[{ }^{\circ} \mathrm{C}\right] \\
\text { opad - rainfall }[\mathrm{mm}]\end{array}$ & $\begin{array}{l}16,5 \\
96,5\end{array}$ & $\begin{array}{l}18,8 \\
82,2\end{array}$ & $\begin{array}{r}17,3 \\
55,1\end{array}$ & $\begin{array}{r}17,6 \\
233,8\end{array}$ \\
\hline
\end{tabular}




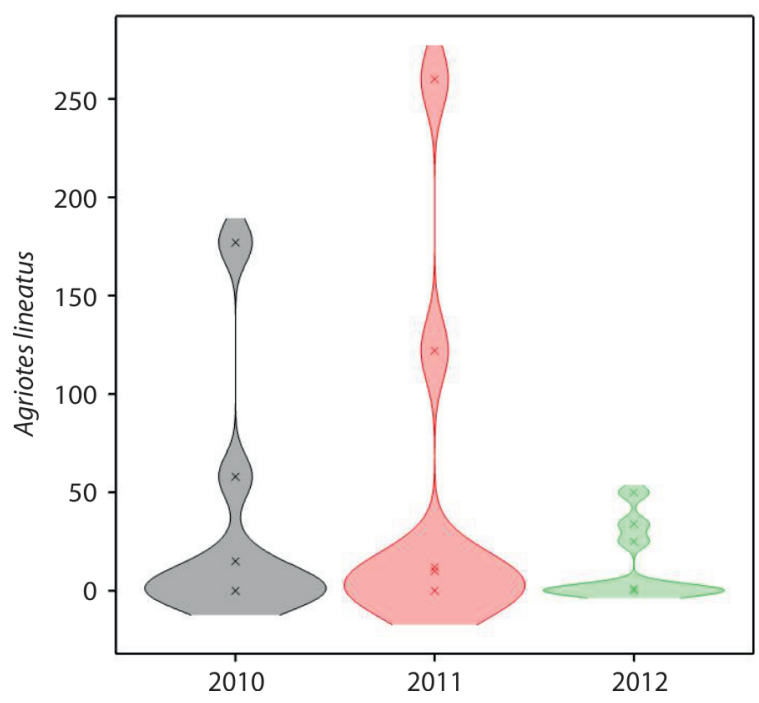

Rys. 1. Wykres gęstości liczebności Agriotes lineatus w poszczególnych latach prowadzenia obserwacji

Fig. 1. Density plot of the number of Agriotes lineatus classified by years of study

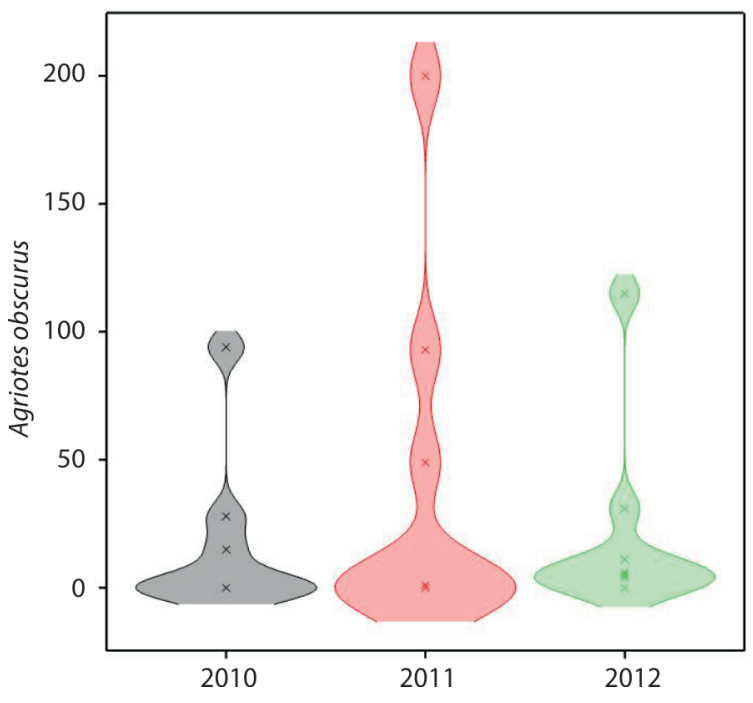

Rys. 2. Wykres gęstości liczebności Agriotes obscurus w poszczególnych latach prowadzenia obserwacji

Fig. 2. Density plot of the number of Agriotes obscurus classified by years of study

Tabela 5. Współczynniki korelacji liniowej Pearsona pomiędzy liczebnościami występowania chrząszczy sprężykowatych poszczególnych gatunków rodzaju Agriotes spp.

Table 5. Linear Pearson's correlations coefficients between the number of specimens of the genus Agriotes spp.

\begin{tabular}{l|c|c|c|c}
\hline & Agriotes lineatus & Agriotes obscurus & Agriotes sputator & Agriotes ustulatus \\
\hline Agriotes lineatus & 1 & & & \\
\hline Agriotes obscurus & $0,6197^{* *}$ & 1 & & \\
\hline Agriotes sputator & $-0,154$ & $-0,1756$ & 1 & \\
\hline Agriotes ustulatus & 0,018 & 0,0845 & 0,1028 & 1 \\
\hline
\end{tabular}

$* * \mathrm{p}<0,01$

od lat badań, warunków pogodowych oraz lokalizacji. Podobne wnioski wyciągnęli Furlan i wsp. (2001), Pusz i wsp. (2013) oraz Jakubowska i Bocianowski (2014). Zarówno w badaniach własnych, jak i innych autorów (Parker i Howard 2001; Erlichowski 2008, 2009, 2011; Hicks i Blackshaw 2008; Landl i wsp. 2010) na liczniejsze występowanie chrząszczy istotny okazał się wpływ warunków pogodowych panujących w poszczególnych sezonach wegetacyjnych oraz wpływ położenia pułapek na polach uprawnych, jak i użytkach śródpolnych w otoczeniu gospodarstwa. Innym ważnym czynnikiem sprzyjającym rozwojowi larw Elateridae i uszkadzaniem przez nie bulw jest niestabilny rozkład temperatur i opadów atmosferycznych w sezonie wegetacyjnym (Benefer i wsp. 2012). Larwy te są bowiem wybitnie higrofilne, co oznacza, że do rozwoju potrzebują dużej wilgotności gleby oraz przemieszczają się stale w profilu glebowym na różne głębokości w poszukiwaniu wody. W okresie suszy, kiedy larwy przebywają głębiej poza zasięgiem bulw, potrafią w momencie poprawy wilgotności ze zdwojoną siłą uszkadzać plon. Duże rozdrobnienie powierzchni gospodarstw (oszczędzanie i ekstensywny profil produkcji w małych gospodarstwach produkujących ziemniaki na małych areałach, tj. 0,5-1 ha) oraz zmiany klimatyczne (długa jesień, ciepłe zimy) wpływają korzystnie na rozwój populacji owadów (Erlichowski 2007; Mrówczyński i wsp. 2007).

Furlan i Tóth (2007) oraz Hicks i Blackshaw (2008) uważają, że monitoring liczebności chrząszczy z wykorzystaniem pułapek feromonowych jest ważnym ogniwem informacji w integrowanych systemach uprawy ziemniaka, oceny ryzyka uszkodzeń, biologii i behawioru szkodnika. Sufyan i wsp. (2011) badając dynamikę dwóch gatunków Elateridae, tj. A. lineatus i A. obscurus w uprawach ziemniaka prowadzonych w systemie ekologicznym, oceniali również skuteczność odławiania znakowanych chrząszczy (samców) w zależności od odległości wypuszczania imago od pułapki. Największą efektywność odłowów stwierdzono, gdy pułapki były oddalone od siebie o 20-40 metrów. W niniejszej pracy najmniej licznie, tj. w Boguchwale (województwo podkarpackie) i w Laskach Koszalińskich (województwo zachodniopomorskie) odławiano $A$. sputator oraz A. ustulus. Buchholz (2008) w swoich bada- 
niach stwierdził, że gatunki te spotykane są bardzo często w agroekosystemach będących ich środowiskiem zastępczym. Agriotes sputator należy w Polsce do najpospolitszych sprężyków upraw rolniczych, a A. ustulatus spotykany bywa często na miedzach i ugorach [w związku z czym określać je można wyłącznie mianem ,potencjalnie (pierwotnie) stepowych"].

W odniesieniu do chrząszczy sprężykowatych wykazano także, że czynnikiem zwabiającym samce osiewników omawianych gatunków był związek chemiczny - geranial. Samice $A$. lineatus wytwarzają oktanian geranylu jako główny składnik feromonu oraz śladowe ilości butynianu geranylu (Tóth i wsp. 2003). Samce A. obscurus reagowały na dyspenser feromonowy składający się z mieszaniny oktanianu geranylu i heksanianu geranylu (Tóth i wsp. 2003). W Europie, głównie na północy kontynentu, w Azji Mniejszej i Rosji oba gatunki występują w mieszanej populacji reagującej głównie na 8-10 zidentyfikowanych komponentów feromonowych, pozyskanych z gruczołów sekrecyjnych samic (Trepashko i Ilyuk 2012).

W Polsce nie poznano dotychczas struktury genetycznej populacji osiewnika rolowca, osiewnika ciemnego i osiewnika skibowca pod kątem występowania określonych „ras feromonowych", stąd też trudno jest dobrać odpowiedni dyspenser zapachowy do ich odłowu. Obecnie na rynku krajowym mniejszą lub większą skutecznością i selektywnością wyróżniają się oferowane dyspensery produkcji węgierskiej i włoskiej. Wiele badań wskazuje, że na skuteczność odławianych samców ma wpływ odpowiednie ustawienie pułapek i warunki meteorologiczne. Ponadto, duży wpływ ma również termin ważności dyspensera feromonowego (przez cały okres badawczy powinna być taka sama skuteczność), warunki jego przechowywania, termin wyłożenia, jego trwałość, zastosowane powłoki klejowe, budowa i zasada działania pułapek chwytnych, bezpośrednie obchodzenie się z dyspenserem, tak aby nie przejął on zapachu ludzkiego, a także miejsce i rozmieszczenie pułapek. Jest to bardzo ważne, gdyż gatunki sprężyków występujące w Polsce najczęściej gromadzą się w trawach, przydrożnych chwastach, gdzie odżywiają się i najczęściej składają jaja (Erlichowski 2011).

Prognozowanie szkód powodowanych przez larwy Elateridae na podstawie liczby odłowionych chrząszczy z zastosowaniem pułapek feromonowych, jak podaje wielu autorów (Neuchoff i Sufyan 2008; Erlichowski 2009; Mangen i wsp. 2011; Benefer i wsp. 2012), należy traktować orientacyjnie dla danej uprawy.

\section{Wnioski / Conclusions}

1. Skuteczność odławianych chrząszczy sprężykowatych za pomocą pułapek feromonowych w poszczególnych miejscowościach była zróżnicowana. Najliczniej odławiano gatunki $A$. lineatus i $A$. obscurus, a najmniej licznie A. ustulatus i A. sputator. Na ich efektywność w dużej mierze miał wpływ przebieg warunków pogodowych, lata badań oraz lokalizacja wystawionych pułapek.

2. Współzależność pomiędzy dynamiką liczebności osobników czterech gatunków osiewników była oceniana na podstawie współczynników korelacji liniowej Pearsona. Jedynie występowanie A. lineatus i A. obscurus było istotnie skorelowane, prawdopodobnie dlatego, że zasiedlają podobne stanowiska.

3. Metoda odławiania osobników dorosłych za pomocą pułapek feromonowych nie ma bezpośredniego wpływu na ograniczenie ich liczebności w środowisku. Zakres oddziaływania pułapek i ich skuteczność są ograniczone tylko do samców, co jest konsekwencją wykorzystywania syntetycznych analogów feromonów płciowych wytwarzanych przez samice.

\section{Literatura / References}

Benefer C.M., Knight M.E., Ellis J.E., Hicks H., Blackshaw R.P. 2012. Understanding the relationship between adult and larval Agriotes distributions: The effect of sampling method, species identification and abiotic variables. Applied Soil Ecology 53: 39-48. DOI: 10.1016/j.apsoil.2011.11.004

Bereś P., Gaj R., Grzebisz W., Kaniuczak Z., Mrówczyński M., Paradowski A., Pruszyński G., Pruszyński S., Siódmiak J., Sulewska H., Tekiela A., Wachowiak H. 2007. Integrowana produkcja kukurydzy (Z. Kaniuczak, S. Pruszyński, red.). Instytut Ochrony Roślin Państwowy Instytut Badawczy, Poznań, 78 ss. ISBN 978-83-89867-16-2.

Boczek J. 1988. Nauka o szkodnikach roślin uprawnych. Wydawnictwo Szkoły Głównej Gospodarstwa Wiejskiego, Warszawa, 432 ss.

Buchholz L. 2008. Sprężyki (Coleoptera: Elateridae, Eucnemidae, Throscidae) rezerwatu leśno-stepowego „Bielinek” nad Odrą - charakterystyka i geneza fauny. [The click-beetles (Coleoptera: Elateridae, Eucnemidae, Throscidae) on the forest-steppe nature reserve"Bielinek" on the Odra river - characteristics and origin of the fauna]. Wiadomości Entomologiczne 27 (4): 195-258.

Erlichowski T. 2007. Nowe metody monitorowania i zwalczania szkodników glebowych (ze szczególnym uwzględnieniem drutowców Elateridae) w uprawach ziemniaka. Wieś Jutra 2 (103): 1-3.

Erlichowski T. 2008. Znaczenie gospodarcze oraz czynniki warunkujące rozwój i szkodliwość szkodników glebowych w uprawie ziemniaka. Wieś Jutra 2 (119): 1-3.

Erlichowski T. 2009. Nowe metody wykrywania obecności sprężykowatych (Coleoptera: Elateridae) w uprawach ziemniaka z wykorzystaniem pułapek przynętowych i feromonowych. [New methods for detecting the presence of Elateridae (Coleoptera: Elateridae) in potato crops using pheromone and bait traps]. Progress in Plant Protection/Postępy w Ochronie Roślin 49 (4): 1691-1696. 
Erlichowski T. 2010. Zwalczanie szkodników glebowych w uprawie ziemniaka - co nowego? [Soil pest control in potato cultivation what's new?]. Ziemniak Polski 20 (2): 42-45.

Erlichowski T. 2011. Zwalczanie drutowców (Coleoptera: Elateridae) w ziemniakach z wykorzystaniem środka zawierającego chloropiryfos. [Control of wireworms (Coleoptera: Elateridae) in potatoes using a chlorpyrifos-containing agent]. Progress in Plant Protection/ Postępy w Ochronie Roślin 51 (3): 1355-1358.

Erlichowski T. 2014. Ochrona plantacji ziemniaka przed szkodnikami glebowymi. Komunikat. [Protection of potato plantations against soil pests statement]. Ziemniak Polski 1: 25-28.

Furlan L., Di Bernardo A., Maini S., Ferrari R., Boriani L., Boriani M., Nobili P., Bourlot G., Turcji A., Vacante V., Monsignore C., Figlioli G., Tóth M. 2001. First practical results of click beetle trapping with pheromone traps in Italy. Proceedings of XXI IWGO Conference, Legnaro, Italia, 27 Octobre-3 Novembre 2001: 277-282.

Furlan L., Tóth M. 2007. Occurrence of click beetle pest spp. (Coleoptera, Elateridae) in Europe as detected by pheromone traps: survey results of 1998-2006. IOBC/WPRS Bulletin 30 (7): 19-25.

GenStat 2007. GenStat Release 10 Reference Manual. Lawes Agricultural Trust, Rothamsted, UK.

Hicks H., Blackshaw R.P. 2008. Differential responses of three Agriotes click beetle species to pheromone trap. Agricultural and Forest Entomology 10 (4): 443-448. DOI: 10.1111/j.1461-9563.2008.00397.x

Jakubowska M., Bocianowski J. 2014. Odłowy sprężykowatych z rodzaju Agriotes spp. przy użyciu pułapek feromonowych w celu sygnalizacji zagrożenia. [Trapping of the Agriotes spp. (Coleoptera: Elateridae) with pheromone traps for the signaling risks]. Annales Universitatis Mariae Curie-Skłodowska, Sectio E, 69 (3): 54-64.

Jakubowska M., Bocianowski J., Nowosad K. 2018. Seasonal fluctuation of Agriotes lineatus, A. obscurus and A. sputator click beetles caught using pheromone traps in Poland. Plant Protection Science 54 (2): 118-127. DOI: 10.17221/39/2016-PPS

Kapsa J., Mrówczyński M., Erlichowski T., Gawińska-Urbanowicz H., Matysek K., Osowski J., Pawińska M., Urbanowicz J., Wróbel S. 2014. Ochrona ziemniaka zgodna z zasadami integrowanej ochrony roślin. Cz. II. Metoda zrównoważonej chemicznej ochrony ziemniaka. [Potato protection according to the principles of integrated pest management Part II. Sustainable method of chemical potato protection]. Biuletyn Instytutu Hodowli i Aklimatyzacji Roślin 273: 145-159.

Landl M., Furlan L., Glauninger J. 2010. Seasonal fluctuation of Agriotes spp. (Coleoptera: Elateridae) at two sites in Austria and the efficiency of bait trap designs for monitoring wireworm populations in the soil. Journal of Plant Diseases Protection 117 (6): $268-272$. DOI: $10.1007 / \mathrm{BF} 03356372$

Mangen M., Landl M., Glauninger J. 2011. Agriotes species: comparison of species composition in pheromone trap catches with larval bait trap catches at the same site. IOBC/WPRS Bulletin 66: 535-537.

Mrówczyński M., Pruszyński G., Wachowiak H., Bereś P. 2007. Nowe zagrożenia upraw rolniczych przez szkodniki ze szczególnym uwzględnieniem kukurydzy. [New endangerment of agricultural crops by pests with specially consideration of maize]. Progress in Plant Protection/Postępy w Ochronie Roślin 47 (1): 323-330.

Neuchoff D., Sufyan M. 2008. Potentials for wireworm control in organic farming. Abstracts of Proceedings EAPR Conference of Brasov, Romania, 6-10 July 2008, s. 297.

Parker W.E., Howard J.J. 2001. The biology and management of wireworms (Agriotes spp.) on potato with particular reference to the U.K. Agricultural and Forest Entomology 3 (2): 85-98. DOI: 10.1046/j.1461-9563.2001.00094.x

Piekarczyk K. 1993. Metody sygnalizacji i prognozowania pojawu chorób i szkodników roślin. W: Instrukcja dla służby ochrony roślin z zakresu prognoz, sygnalizacji i rejestracji (S. Pruszyński, red.). Cz. II (1-2). Instytut Ochrony Roślin, Poznań, 123 ss.

Pusz M., Bawoł S., Jakubowska M. 2013. Efektywność odłowów gatunków z rodzin Noctuidae i Elateridae za pomocą pułapek feromonowych w powiecie olsztyńskim, w latach 2011-2012. [The effectiveness catches of Noctuidae and Elateridae families with pheromone traps in Olsztyn district, in 2011-2012]. Progress in Plant Protection/Postępy w Ochronie Roślin 53 (4): 697-703. DOI: 10.14199/ppp-2013-008

Sufyan M., Neuhoff D., Furlan L. 2011. Assessment of the range of attraction of pheromone traps to Agriotes lineatus and Agriotes obscurus. Agricultural and Forest Entomology 13 (3): 313-319. DOI: 10.1111/j.1461-9563.2011.00529.x

Tarnawski D. 2000. Fauna Polski/Fauna Poloniae. Elateridae - Sprężykowate (Insecta: Coleoptera). Cz. I. Polskie Towarzystwo Entomologiczne, Warszawa, 235 ss.

Tóth M., Furlan L., Yatsynin V.G., Ujváry I., Szurukán I., Imrei Z., Tolasch T., Francke W., Jossi W. 2003. Identification of pheromones and optimization of bait composition for click beetle pests (Coleoptera: Elateridae) in Central and Western Europe. Pest Management Science 59 (4): 417-425. DOI: 10.1002/ps.629

Tratwal A., Strażyński P., Bereś P., Korbas M., Danielewicz J., Jajor E., Horoszkiewicz-Janka J., Jakubowska M., Roik K., Baran M., Wielkopolan B., Kubasik W., Klejdysz T., Węgorek P., Zamojska J., Dworzańska D., Barłóg P. 2018. Poradnik sygnalizatora ochrony bobowatych drobnonasiennych. Instytut Ochrony Roślin - Państwowy Instytut Badawczy, Poznań, 245 ss. ISBN 978-83-6465541-8.

Trepashko L., Ilyuk O. 2012. Monitoring feromonowy sprężykowatych jako podstawa do prognozowania szkód i celowości zabiegów chemicznych. [Pheromone monitoring of click beetles as a basis of elaters harmfulness forecast and sustainable insecticide application]. Progress in Plant Protection/Postępy w Ochronie Roślin 52 (4): 859-863. DOI: 10.14199/ppp-2012-148

Walczak F., Bandyk A., Jakubowska M., Roik K., Tratwal A., Złotkowski J. 2011. Stan fitosanitarny roślin uprawnych w Polsce w roku 2010 i spodziewane wystąpienia agrofagów w roku 2011. Instytut Ochrony Roślin, Poznań, 110 ss. ISSN 1898-7419.

Walczak F., Bandyk A., Jakubowska M., Roik K., Tratwal A., Wielkopolan B., Złotkowski J. 2012. Stan fitosanitarny roślin uprawnych w Polsce w roku 2011 i spodziewane wystąpienia agrofagów w roku 2012. Instytut Ochrony Roślin, Poznań, 122 ss. ISSN $1898-7419$.

Walczak F., Bandyk A., Jakubowska M., Roik K., Tratwal A., Wielkopolan B., Złotkowski J. 2013. Stan fitosanitarny roślin uprawnych w Polsce w roku 2012 i spodziewane wystąpienia agrofagów w roku 2013. Instytut Ochrony Roślin, Poznań, 120 ss. ISSN $1898-7419$. 